\title{
ARMANDO OYARZÚN KONG
}

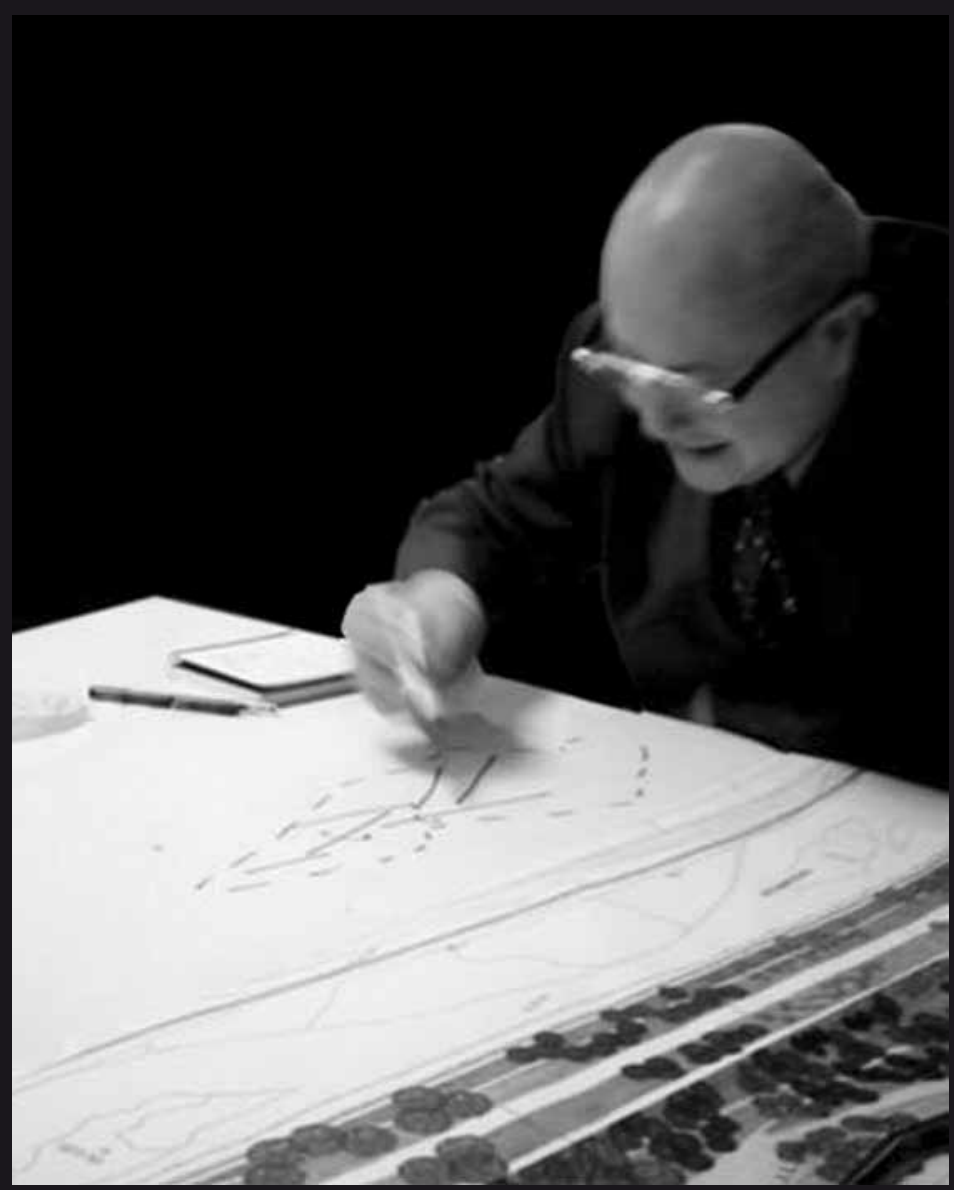

La noticia nos golpeó duro un cálido fin de semana de enero. Víctima de un coma diabético falleció Armando Oyarzún, notable arquitecto diseñador y dibujante, carismático profesor y sobre todo amigo entrañable.

Su muerte inesperada nos impactó fuertemente entre quienes fuimos sus amigos y trabajamos con él. Pero fue especialmente dura para los alumnos con quienes tenía una comunicación y un cariño especial.

Auténtico creativo, crítico vehemente, muchas veces resultó incomprendido por su tenacidad y su voluntarismo.

Barcelona lo acogió durante más de 20 años donde pudo desarrollar su talento como arquitecto, artista, curador de exposiciones y editor de libros. Regresó a Chile a comenzar una nueva etapa, esta vez como profesor universitario. Dictó clases en la Universidad de Chile, en la Universidad de Santiago, en la Universidad Las Américas y en la UCINF.

Su interés y entusiasmo por la extensión lo llevó a dirigir la Unidad de Extensión de nuestra Facultad y a crear el sitio web Museo Virtual de Arquitectura y Diseño Contemporáneo (www.mvadc.cl).

Su temprana partida ocurre en los momentos en que acababa de recibir su título de arquitecto en la USACH con nota máxima, después de 38 años de ingresar a la Escuela de Arquitectura de la Universidad de Chile. Se aprestaba a iniciar una nueva etapa en su vida, llena de proyectos en el campo de la arquitectura, la difusión y las publicaciones. Sin embargo la muerte se interpuso entre sus planes y aún no logramos entender su significado ni asimilar su ausencia. 